\title{
Comparative Analysis of Low-Grade Heat Utilization Methods for Thermal Power Plants with Back-Pressure Steam Turbines
}

\author{
Nikolay Rogalev ${ }^{1}$, Vladimir Kindra ${ }^{2, *(\mathbb{D})}$, Ivan Komarov ${ }^{2}$, Sergey Osipov ${ }^{2}$, Olga Zlyvko ${ }^{2}$ and Dmitrii Lvov $^{2}$ \\ 1 Department of Thermal Power Plants, National Research University "Moscow Power Engineering Institute", \\ 111250 Moscow, Russia; rogalevND@mpei.ru \\ 2 Department of Innovative Technologies of High-Tech Industries, National Research University “Moscow \\ Power Engineering Institute", 111250 Moscow, Russia; komarovii@mpei.ru (I.K.); osipovsk@mpei.ru (S.O.); \\ zlyvkoov@mpei.ru (O.Z.); lvovDD@mpei.ru (D.L.) \\ * Correspondence: kindra.vladimir@yandex.ru
}

Citation: Rogalev, N.; Kindra, V.; Komarov, I.; Osipov, S.; Zlyvko, O.; Lvov, D. Comparative Analysis of Low-Grade Heat Utilization Methods for Thermal Power Plants with Back-Pressure Steam Turbines. Energies 2021, 14, 8519. https:// doi.org/10.3390/en14248519

Academic Editor: Bruno Facchini

Received: 18 November 2021 Accepted: 15 December 2021 Published: 17 December 2021

Publisher's Note: MDPI stays neutral with regard to jurisdictional claims in published maps and institutional affiliations.

Copyright: (C) 2021 by the authors Licensee MDPI, Basel, Switzerland. This article is an open access article distributed under the terms and conditions of the Creative Commons Attribution (CC BY) license (https:// creativecommons.org/licenses/by/ $4.0 /)$.
Abstract: Thermal power plants (TPPs) with back-pressure steam turbines (BPSTs) were widely used for electricity and steam production in the Union of Soviet Socialist Republics (USSR) due to their high efficiency. The collapse of the USSR in 1991 led to a decrease in industrial production, as a result of which, steam production in Russia was reduced and BPSTs were left without load. To resume the operation of TPPs with BPSTs, it is necessary to modernize the existing power units. This paper presents the results of the thermodynamic analysis of different methods of modernization of TPPs with BPSTs: the superstructure of the steam low-pressure turbine (LPT) and the superstructure of the power unit operating on low-boiling-point fluid. The influence of ambient temperature on the developed cycles' efficiency was evaluated. It was found that the usage of low-boiling-point fluid is thermodynamically efficient for an ambient temperature lower than $7^{\circ} \mathrm{C}$. Moreover, recommendations for the choice of reconstruction method were formulated based on technical assessments.

Keywords: low-boiling-point fluid; thermodynamic optimization; efficiency; average annual temperature; net power; superstructure; layout

\section{Introduction}

\subsection{The Problem of the Exhaust Heat Utilization for Back-Pressure Steam Turbines}

Increasing the efficiency of electricity production at thermal power plants is an urgent task that ensures a reduction in the consumption of organic fuel and emissions of toxic substances and greenhouse gases. Simultaneously, it is possible to both create new efficient power generation units and to modernize existing installations through the implementation of superstructures.

The main direction for efficiency improvement of gas turbine, steam turbine, and combined cycle power plants is the growth of the initial parameters. To date, the maximum value of working fluid temperature is $620{ }^{\circ} \mathrm{C}[1,2]$ for steam turbine TPPs and $1650{ }^{\circ} \mathrm{C}$ for gas turbine TPPs [3-5]. Further temperature growth is possible but hampered by the necessity to develop heat-resistant alloys and thermal barrier coatings [6], as well as promising cooling systems $[7,8]$.

Among such methods, cogeneration became widely used in countries with a low average annual temperature, causing a significant demand for the heating load. Combined heat and power production (CHP) was the long-term method for efficiency improvement in USSR power plants. CHP power plants with turbines T-50, T-100, T-180, and T-250 were widely used. Additionally, steam turbine power plants (STPPs) with industrial steam delivery equipped with the BPSTs of P-50 and P-100 families were applied, allowing minimal heat energy losses. After the disintegration of the USSR, the demand for industrial steam delivery drastically decreased. As a result, many TPPs with industrial steam delivery were decommissioned. 
The Russian energy fleet operated 68 steam turbines of the P-50 family and 18 steam turbines of the P-100 family, with a total power of $5.2 \mathrm{GW}$. In the early 21st century, their average annual load was as low as $37 \%$, or $1.9 \mathrm{GW}$ [9]. The long-term shutoff of power units caused an absence of the steam and power selling income and the occurrence of additional expenses for maintaining the equipment's operational status. Powerful block shutdown expenses are approximately $6000-10,000 \mathrm{MW} /$ year $[10,11]$. The world's power consumption is growing continuously; therefore, efficiency improvement and increased electric power delivery in the existing BPST power units that stand idle are topical targets due to the absence of steam delivery.

The described problem may be solved in various ways. The most obvious is the addition of an accessory steam turbine (AST), which operates at a relatively low inlet pressure that is equal to the BPST outlet pressure of 0.9 to $1.5 \mathrm{MPa}$ and a condenser. Equipment manufacturers have developed various new types of sequentially connected additional steam turbines, including PT-45-15, K-45-15, T-70-16, and others. It should be noted that the last stages of ASTs have high steam humidity, which could be decreased by intermediate steam superheating in the boiler. However, this solution is reasonable for the block-type layout of TPPs, in which steam from a single boiler is directed to a single turbine. Investigations [12] show that the introduction of BPSTs with ASTs allows a double increase in TPP power production and an improvement of the existing TPP efficiency at a relatively low cost of USD 150-200/KW.

Another method proposes the use of an intermediate-pressure turbine (IPT) and the LPT of other turbines, which need a high-pressure turbine (HPT) replacement, and whose IPT and LPT operation may be continued, as an AST [9]. This method's advantage is its low price. On the other hand, the method application assumes the availability of a turbine, which allows an increase in steam flow capacity.

Another prospective method of BPST modification is the utilization of exhaust steam heat using the superstructure of the cycle with low-boiling-point fluid [13-15]. This method has some advantages over the LPT superstructure. Most of the low-boiling-point heat carriers work in a cycle with a high pressure, providing high density, which allows the compactness of turbomachines and other equipment. Additionally, the application of a low-boiling heat carrier eliminates excessive moisture production in the turbine, which results in a high flowpath efficiency. However, the introduction of this method requires additional capital investments related to the necessary application of turbine and heat exchanger equipment to operate on the low-boiling heat carrier.

\subsection{Existing Solution for Integration of Low-Boiling-Point Fluid Cycles in TPPs with BPSTs}

A few papers disclose the potential utilization of TPPs with BPSTs. The common feature of these works is TPP modification using the superstructure of cycles with lowboiling organic heat carriers, including butane and various Freons.

In [16], a combined power plant with a BPST was described, in which exhaust steam was shared between the heat consumer (HC) and cycle with low-boiling-point fluid. The unit employs steam and organic fluid Rankine cycles. The results of the analysis showed that it is reasonable to use pentane in the temperature range of $140-190{ }^{\circ} \mathrm{C}$ and butane in the temperature range of $100-130^{\circ} \mathrm{C}$. The low-potential thermal energy transforms into mechanical energy and further into electricity and is transferred into the closed butane cycle, which includes a steam generator, a butane turbine with a generator, a butane condenser, pumps, and auxiliary equipment. The power consumption for liquid butane compression is reduced by the application of multi-stage compression in the condensate pump and injectors. It should be noted that the main shortage of the considered low-boiling heat carriers is their explosion hazard.

In [13], a power facility for the utilization of low-potential steam energy in a condenser is described. The facility consists of a condensing steam turbine whose condenser is connected to a cycle with a low-boiling-point fluid. The low-temperature cycle includes the following equipment: vaporizing and superheating heat exchanger surfaces, and a 
carbon dioxide turbine with a generator, a condenser, a regenerator, pumps, and auxiliary equipment. The superstructure resulted in a TPP net efficiency increase of 1.6\%.

The key factor defining the thermodynamic effect from the considered BPST modifications is the ambient temperature, which remarkably influences the additional turbine heat reduction. The investigation of this factor's influence on the electricity output is a topical problem which has not been considered before. This work is devoted to the development of approved recommendations for the choice of prospective methods for existing BPST modification. The modifications must increase the electric power output and improve the power production net efficiency.

\section{Research Objective}

\subsection{A State of the Art Review of TPPs with BPSTs}

The BPST facilities in Russia may be split into the following four groups:

1. Facilities with unchanged load (Group 1);

2. Modified facilities (Group 2);

3. Facilities with remarkably reduced load (Group 3);

4. Decommissioned facilities (Group 4).

The most interesting objects for the modification are the Groups 3 and 4 facilities. The key performances of these facilities are summarized in Table 1. The data show that all 12 BPSTs of 9 TPPs belong to the P-50 family and have transversal connections. Eight facilities use natural gas as fuel and the remaining five use coal. The reduced demand for industrial steam delivery forced the decommissioning of eight BPSTs and a load reduction of $30-50 \%$ for the remaining five power units. These specific features must be taken into account, choosing possible options for modifying power units. The scheme, main characteristics, and parameters of the P-50-130/13 power unit are shown in Figure 1 and Table 2. Live steam enters a steam turbine (BPST) from the main steam pipe (MSP), which represents a common steam collector for TPPs with transversal connections. The generator $(G)$ is mounted onto the steam turbine shaft. The turbine exhaust steam is supplied to the heat consumer and returns to the condensate form. The condensate pump (CP) supplies the condensate to the deaerator (D), where the turbine exhaust steam and the bleeding downstream of the high-pressure heater (HPHX-3) are also supplied. The water pressure is increased in the feed pump (FP). Then, the water is heated in three high-pressure heaters (HPHX-1, HPHX-2, and HPHX-3) by the heat of the steam from the turbine bleedings. After the HPHX-1, the feed water enters the MSP.

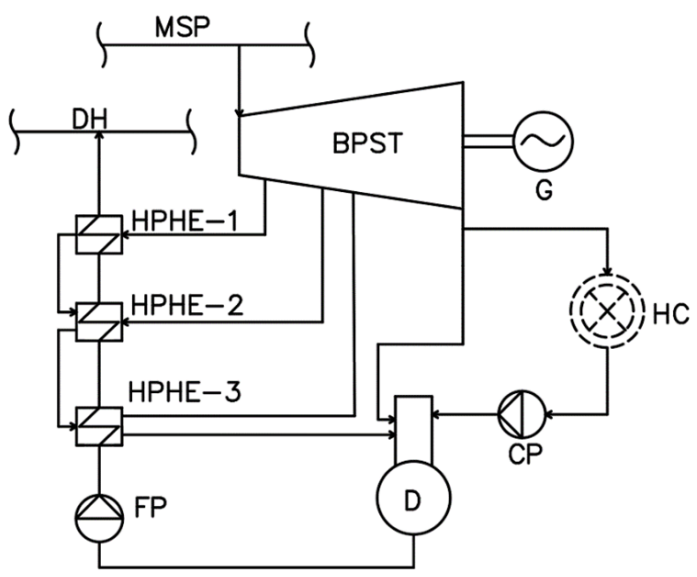

Figure 1. The scheme of steam turbine unit with BPST P-50-130/13 (Case 1): MSP-main steam pipe; BPST—back-pressure steam turbine; $\mathrm{G}$-generator; $\mathrm{HC}$ - heat consumer; $\mathrm{CP}$-condensate pump; $\mathrm{D}$ deaerator; FP—feed pressure; HPHE-1,2,3—high-pressure heat exchangers; DH—discharge header. 
Table 1. Characteristics of TPPs with BPSTs operated with low load or decommissioned.

\begin{tabular}{|c|c|c|c|c|}
\hline № & TPP Name/Russia Region & $\begin{array}{c}\text { Average Annual } \\
\text { Temperature/Type of Fuel }\end{array}$ & Turbine Marking/TPP Layout & BPST Current State \\
\hline 1 & Balakovo CHP/Saratov region & $\begin{array}{l}7.1^{\circ} \mathrm{C} / \\
\text { natural gas }\end{array}$ & $\begin{array}{l}\text { P-50-130/13/ } \\
\text { unknown }\end{array}$ & decommissioned \\
\hline 2 & $\begin{array}{c}\text { Novocheboksarskaya } \\
\text { CHP-3/Chuvashiya republic }\end{array}$ & $\begin{array}{l}3.5^{\circ} \mathrm{C} / \\
\text { natural gas }\end{array}$ & $\begin{array}{c}\mathrm{P}-25-130 / 13 / \\
\text { transversal connections }\end{array}$ & $\begin{array}{l}\text { load reduced by } 50 \% \\
\text { (from } 50 \text { to } 25 \mathrm{MW} \text { ) }\end{array}$ \\
\hline 3 & Kazan CHP-2/Tatarstan republic & $\begin{array}{l}4.0^{\circ} \mathrm{C} / \\
\text { natural gas }\end{array}$ & $\begin{array}{c}\mathrm{P}-25-130 / 13 / \\
\text { transversal connections }\end{array}$ & $\begin{array}{l}\text { load reduced by } 50 \% \\
\text { (from } 50 \text { to } 25 \mathrm{MW} \text { ) }\end{array}$ \\
\hline 4 & $\begin{array}{c}\text { Nizhegorodskaya } \\
\text { TPP/Nizhegorodskaya region }\end{array}$ & $\begin{array}{l}5.9^{\circ} \mathrm{C} / \\
\text { natural gas }\end{array}$ & $\begin{array}{l}\text { P-32-130/13/ } \\
\text { unknown }\end{array}$ & $\begin{array}{l}\text { load reduced by } 36 \% \\
\text { (from } 50 \text { to } 32 \mathrm{MW} \text { ) and } \\
\text { decommissioned }\end{array}$ \\
\hline 5 & Saratov CHP-2/Saratov region & $\begin{array}{l}7.1^{\circ} \mathrm{C} / \\
\text { natural gas }\end{array}$ & $\begin{array}{l}\text { P-50-130/13/ } \\
\text { unknown }\end{array}$ & decommissioned \\
\hline 6 & Sterlitamak CHP/Bashkortostan republic & $\begin{array}{l}4.9^{\circ} \mathrm{C} / \\
\text { natural gas }\end{array}$ & $\begin{array}{c}2 \times \mathrm{P}-50-130 / 13 / \\
\text { transversal connections }\end{array}$ & decommissioned \\
\hline 7 & Irkutsk CHP-9/Irkutsk region & $\begin{array}{c}2.2^{\circ} \mathrm{C} / \\
\text { coal }\end{array}$ & $\begin{array}{c}\mathrm{P}-50-130 / 13 / \\
\text { transversal connections }\end{array}$ & decommissioned \\
\hline 8 & Kemerovo TPP/Kemerovo region & $\begin{array}{c}1.5^{\circ} \mathrm{C} / \\
\text { coal }\end{array}$ & $\begin{array}{l}\text { P-35-130/30/15, P-35-130/30/ } \\
\text { transversal connections }\end{array}$ & $\begin{array}{l}\text { load reduced by } 30 \% \\
\text { (from } 50 \text { to } 35 \mathrm{MW} \text { ) }\end{array}$ \\
\hline 9 & Novo-Kemerovo CHP / Kemerovo region & $\begin{array}{l}1.5^{\circ} \mathrm{C} / \\
\text { coal }\end{array}$ & $\begin{array}{l}\mathrm{P}-50-130 / 13, \mathrm{P}-50-130 / 18 / \\
\text { transversal connections }\end{array}$ & decommissioned \\
\hline
\end{tabular}

Table 2. Main characteristics and parameters of the P-50-130/13.

\begin{tabular}{cc} 
Parameter & Value \\
\hline Turbine inlet mass flow, $\mathrm{kg} / \mathrm{s}$ & 116.6 \\
Turbine inlet pressure, $\mathrm{MPa}$ & 12.8 \\
Turbine inlet temperature, ${ }^{\circ} \mathrm{C}$ & 555 \\
Turbine exit pressure, $\mathrm{MPa}$ & 1.5 \\
Turbine exit temperature, ${ }^{\circ} \mathrm{C}$ & 258 \\
Turbine internal relative efficiency, $\%$ & 89 \\
Mechanical efficiency, $\%$ & 99 \\
Power generator efficiency, $\%$ & 99 \\
Feed water temperature, ${ }^{\circ} \mathrm{C}$ & 234 \\
Pressure in deaerator, MPa & 5 \\
Feed pump internal relative efficiency, $\%$ & 0.6 \\
Condensate pump internal relative efficiency, $\%$ & 75 \\
Feed pump outlet pressure, $\mathrm{MPa}$ & 0.89 \\
Pressure in the first steam turbine bleed, $\mathrm{MPa}$ & 1.34 \\
Pressure in the second steam turbine bleed, $\mathrm{MPa}$ & 34.4 \\
Relative pressure losses in turbine bleeds, $\%$ & 21.9 \\
\hline
\end{tabular}

When the industrial heat consumer was absent, the main source of low-potential heat was the P-50-130/13 turbine exhaust steam. The possibility of utilizing the boiler exhaust gases was not considered here as there were no power plants with the block layout of the boiler and turbine, as shown in Table 1.

The BPST exhaust steam thermal energy may be reasonably utilized in a condensertype heat exchanger. At the turbine exhaust pressure of $1.5 \mathrm{MPa}$, the steam condensation temperature was $198.3^{\circ} \mathrm{C}$. Together with the $5^{\circ} \mathrm{C}[17,18]$ low-boiling point fluid underheating, the low-potential circuit maximal temperature was $193.3^{\circ} \mathrm{C}$. It was important to consider this in the choice of the low-boiling point heat carrier. 


\subsection{Choice of the Low-Boiling Point Heat Carrier for Heat Utilization of the Turbine Exhaust Steam}

When choosing a low-boiling point heat carrier, the following factors must be taken into account:

1. The thermophysical properties of the heat carrier, providing a maximum increase in power production;

2. Low toxicity;

3. No environmental harm (ozone layer depletion, the greenhouse effect);

4. Low cost for the heat carrier;

5. A heat carrier that does not freeze at the ambient temperature (especially important for northern regions).

Thermodynamic studies of the heat carrier type [19-22] show that it is reasonable to use the following Freon types in the $170-250{ }^{\circ} \mathrm{C}$ temperature range: R123, R365mfc, R601a, R601, and R141. Additionally, according to [16], it is reasonable to involve pentane in the 140-190 ${ }^{\circ} \mathrm{C}$ temperature range. As a result, the research data presented in [22-24] show the advantages of the carbon dioxide heat carrier. In particular, its high specific mass allows the compactness of equipment. Moreover, the price of carbon dioxide is relatively low.

It is important to take into consideration factors such as price, toxicity, and danger of explosion and environmental harm (ozone depletion and global warming effects). Table 3 summarizes the factor analysis results which allowed the evaluation of different heat carriers.

Table 3. Availability, safety, and environmental data of the low-boiling-point fluid.

\begin{tabular}{cccccc}
\hline & & \multicolumn{2}{c}{ Safety Data } & \multicolumn{2}{c}{ Environmental Data } \\
\cline { 3 - 6 } Substance & $\begin{array}{c}\text { Relative } \\
\text { Price }\end{array}$ & Toxicity & $\begin{array}{c}\text { Danger of } \\
\text { Explosion }\end{array}$ & $\begin{array}{c}\text { Ozone } \\
\text { Depletion }\end{array}$ & $\begin{array}{c}\text { Global } \\
\text { Warming }\end{array}$ \\
\hline R123 & average & + & - & + & - \\
R365mfc & high & - & - & - & + \\
R601a & high & - & + & - & - \\
R601 & high & - & + & + & - \\
R141 & average & - & - & - & + \\
$\mathrm{C}_{5} \mathrm{H}_{12}$ & low & + & + & - & + \\
$\mathrm{CO}_{2}$ & low & - & - & + \\
\hline
\end{tabular}

The pressure levels were high for cycles with low-boiling-point fluid, so working fluid leakages may have been considerable. Therefore, the first criterion for the heat carrier choice must be operation safety. In this regard, the R123, R601a, R601, and $\mathrm{C}_{5} \mathrm{H}_{12}$ heat carriers were not considered in this work.

Two of the remaining heat carriers, R365mfc and R141, cause ozone layer depletion, and the cheapest $\mathrm{CO}_{2}$ amplifies the greenhouse effect. Among these heat carriers, carbon dioxide has a high specific mass which allows the compactness of the equipment. The factors above determined the carbon dioxide choice for the heat utilization of the turbine exhaust steam of BPSTs.

\subsection{Prospective Modernization Methods of TPPs with BPSTs}

The scheme of the power unit with BPST shown in Figure 1 was considered as a base case (Case 1). Most of the power plants with BPST have transversal connections between the boiler and turbine. Therefore, this work considered only two modernization versions:

- The superstructure of the accessory steam turbine (Case 2a, Figure 2a);

- The superstructure of the low-boiling point $\mathrm{CO}_{2}$ cycle (Case $2 b$, Figure $2 b$ ). 


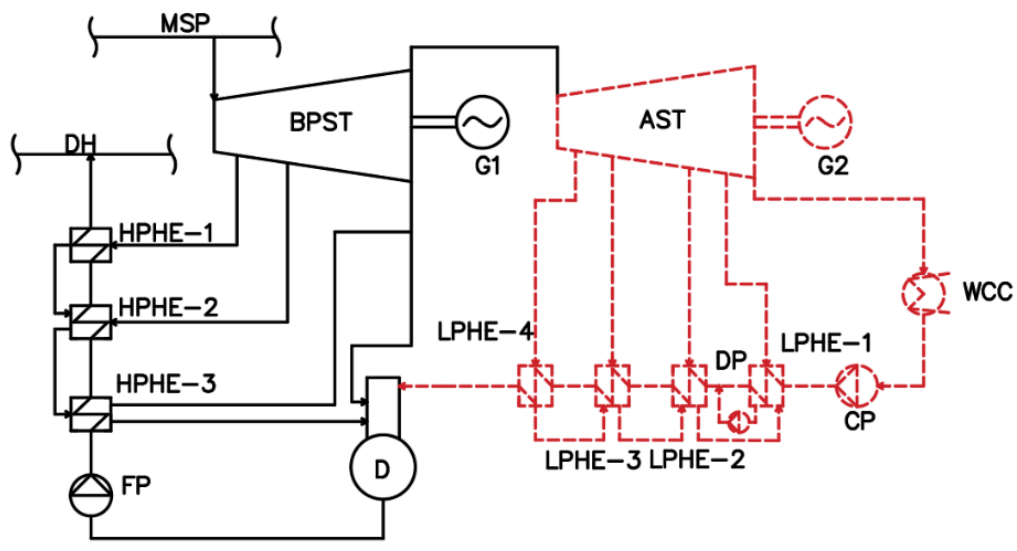

(a)

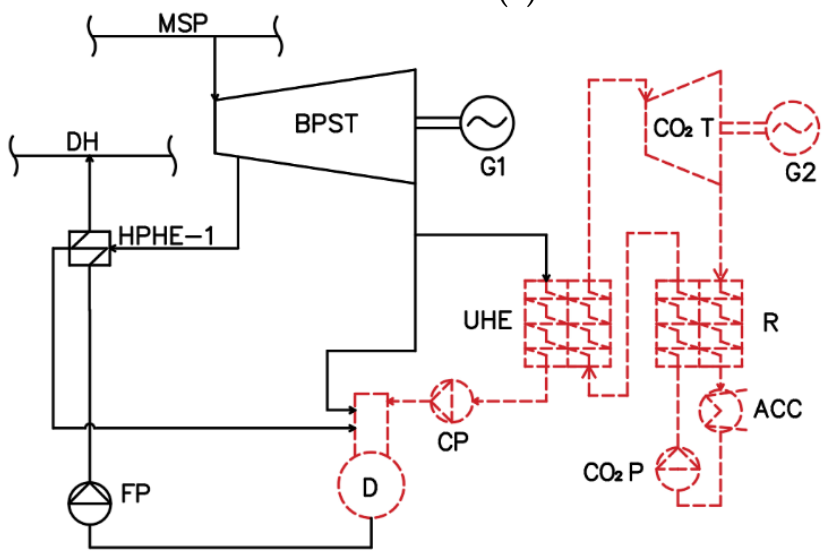

(b)

Figure 2. Prospective methods for BPST power unit modernization. (a) AST superstructure (Case 2a): AST-accessory steam turbine; G2-generator; WCC—water-cooled cooler; LPHE-1,2,3,4-lowpressure heat exchangers; $\mathrm{D}$-deaerator; $\mathrm{DP}$-drainline pump. (b) $\mathrm{CO}_{2}$ cycle superstructure (Case 2b): $\mathrm{CO}_{2} \mathrm{~T}$-dioxide carbon turbine; $\mathrm{R}$-regenerator; $\mathrm{ACC}$-air-cooled cooler; $\mathrm{CO}_{2} \mathrm{P}$-dioxide carbon pump; UHE-utilization heat exchanger.

In the first scheme, the low-pressure turbine, condenser, and condensate pump were connected to the BPST exhaust. In the second scheme, a low-boiling point heat carrier cycle was built. The input data for a heat flow analysis of the schemes shown in Figures 1 and 2 are summarized in Tables 1, 4, and 5 [25-27].

It should be noted that the implementation of both variants of modifications of TPPs with BPSTs involved the purchase of additional equipment and the exclusion of part of the existing equipment. Tables 6 and 7 summarize information on the necessary replacement of power equipment for the modification options.

Table 4. Simulation input data for Case 2a.

\begin{tabular}{cc}
\hline Parameter & Value \\
\hline Low-pressure heat exchanger minimal temperature reduction, ${ }^{\circ} \mathrm{C}$ & 5 \\
Condenser minimal temperature reduction, ${ }^{\circ} \mathrm{C}$ & 10 \\
Low-pressure turbine internal relative efficiency, $\%$ & 84 \\
Pressure in the first bleed of LPT, MPa & 0.14 \\
Pressure in the second bleed of LPT, $\mathrm{MPa}$ & 0.20 \\
Pressure in the third bleed of LPT, $\mathrm{MPa}$ & 0.27 \\
Pressure in the fourth bleed of LPT, $\mathrm{MPa}$ & 0.37 \\
\hline
\end{tabular}


Table 5. Simulation input data for Case $2 b$.

\begin{tabular}{cc} 
Parameter & Value \\
\hline $\mathrm{CO}_{2}$ turbine inlet pressure, $\mathrm{MPa}$ & 19 \\
$\mathrm{CO}_{2}$ turbine inlet temperature, ${ }^{\circ} \mathrm{C}$ & 193 \\
$\mathrm{CO}_{2}$ turbine internal relative efficiency, $\%$ & 90 \\
$\mathrm{CO}_{2}$ condenser minimal temperature reduction, ${ }^{\circ} \mathrm{C}$ & 10 \\
$\mathrm{CO}_{2}$ regenerator minimal temperature reduction, ${ }^{\circ} \mathrm{C}$ & 5 \\
Utilization of heat exchanger minimal temperature reduction, ${ }^{\circ} \mathrm{C}$ & 5 \\
Pressure in deaerator, $\mathrm{MPa}$ & 1.83 \\
\hline
\end{tabular}

Table 6. New power generation equipment for modification of TPPs with BPSTs.

\begin{tabular}{ccc}
\hline № & $\begin{array}{c}\text { New Power Generation Equipment for } \\
\text { Case 2a }\end{array}$ & $\begin{array}{c}\text { New Power Generation Equipment for } \\
\text { Case 2b }\end{array}$ \\
\hline 1 & Accessory steam turbine & $\mathrm{CO}_{2}$ turbine \\
2 & Generator 2 & Generator 2 \\
3 & Water cooled condenser & Air cooled condenser \\
4 & Condensate pump (high-pressure) & Condensate pump (high-pressure) \\
5 & Low-pressure heat exchangers (LPHE-1, & Regenerator \\
6 & LPHE-2, LPHE-3, LPHE-4) & $\mathrm{CO}_{2}$ pump \\
7 & Drainline pump & Utilization of heat exchanger \\
8 & - & Deaerator (high-pressure) \\
\hline
\end{tabular}

Table 7. Removal of power generation equipment for modification of TPPs with BPSTs.

\begin{tabular}{ccc}
\hline № & $\begin{array}{c}\text { Removal of Power Generation } \\
\text { Equipment for Case 2a }\end{array}$ & $\begin{array}{c}\text { Removal of Power Generation } \\
\text { Equipment for Case 2b }\end{array}$ \\
\hline 1 & Condensate pump (low-pressure) & $\begin{array}{c}\text { Condensate pump (low-pressure) } \\
\text { Deaerator (low-pressure) }\end{array}$ \\
\hline
\end{tabular}

\section{Methods}

Thermodynamic studies of the thermal power plants with back-pressure steam turbines were carried out using the AspenONE code. The thermo-physical performance of the operating fluid was calculated using the NIST REFPROP database.

The simulation flowcharts are shown in Figure 3. The schemes presented in Figure 3a include a back-pressure turbine, a low-pressure turbine, a water-cooled condenser, a condensate pump, low-pressure heat exchangers-1,2,3, a drainline pump, a deaerator, a feed pump, and high-pressure heat exchangers-1,2,3. The schemes presented in Figure $3 b$ include a back-pressure turbine, a $\mathrm{CO}_{2}$ turbine, an air-cooled condenser, a $\mathrm{CO}_{2}$ pump, a regenerator, a utilization heat exchanger, a condensate pump, a deaerator, a feed pump, and an HPHE-1.

Most TPPs with BPSTs have a layout with transversal connections. Therefore, a net power increment was chosen as the main criterion for thermodynamic assessment, which was defined as follows:

$$
\Delta N_{\text {net }}^{e}=N_{\text {net_i } i}^{e}-N_{\text {net_1 }}^{e} \text {, }
$$

where $N_{\text {net_ }}^{e} 1$ is the net power for Case 1, MW; $N_{\text {net } \_i}^{e}$ is the net power for Cases $2 \mathrm{a}$ and 2b, MW.

The net power was defined as follows:

$$
N_{\text {net }}^{e}=N_{b r u t}^{e}-N_{O N}^{e},
$$

where $N_{b r u t}^{e}$ is the gross power, MW; $N_{O N}^{e}$ is the own needs, MW.

The gross power for Case 1 was defined as follows:

$$
N_{b r u t \_1}^{e}=\left(N_{1_{1}}+N_{1_{2}}+N_{1_{3}}\right) \cdot \eta_{m e c h} \cdot \eta_{e g},
$$


where $N_{1_{1}}$ is the internal power of the first BPST compartment, MW; $N_{1_{2}}$ is the internal power of the second BPST compartment, MW; $N_{1_{3}}$ is the internal power of the third BPST compartment, MW, $\eta_{\text {mech }}$ is the mechanical efficiency; and $\eta_{e g}$ is the power generator efficiency.

The gross power for Case 2a was defined as follows:

$$
N_{b r u t \_2 a}^{e}=\left(\left(N_{1_{1}}+N_{1_{2}}+N_{1_{3}}\right)+\left(N_{2 a_{1}}+N_{2 a_{2}}+N_{2 a_{3}}+N_{2 a_{4}}+N_{2 a_{5}}\right)\right) \cdot \eta_{m e c h} \cdot \eta_{e g},
$$

$N_{2 a_{1}}$ is the internal power of the first LPT compartment, MW; $N_{2 a_{2}}$ is the internal power of the second LPT compartment, MW; $N_{2 a_{3}}$ is the internal power of the third LPT compartment, MW; $\mathrm{N}_{2 a_{4}}$ is the internal power of the fourth LPT compartment, MW; and $\mathrm{N}_{2 a_{5}}$ is the internal power of the fifth LPT compartment, MW.

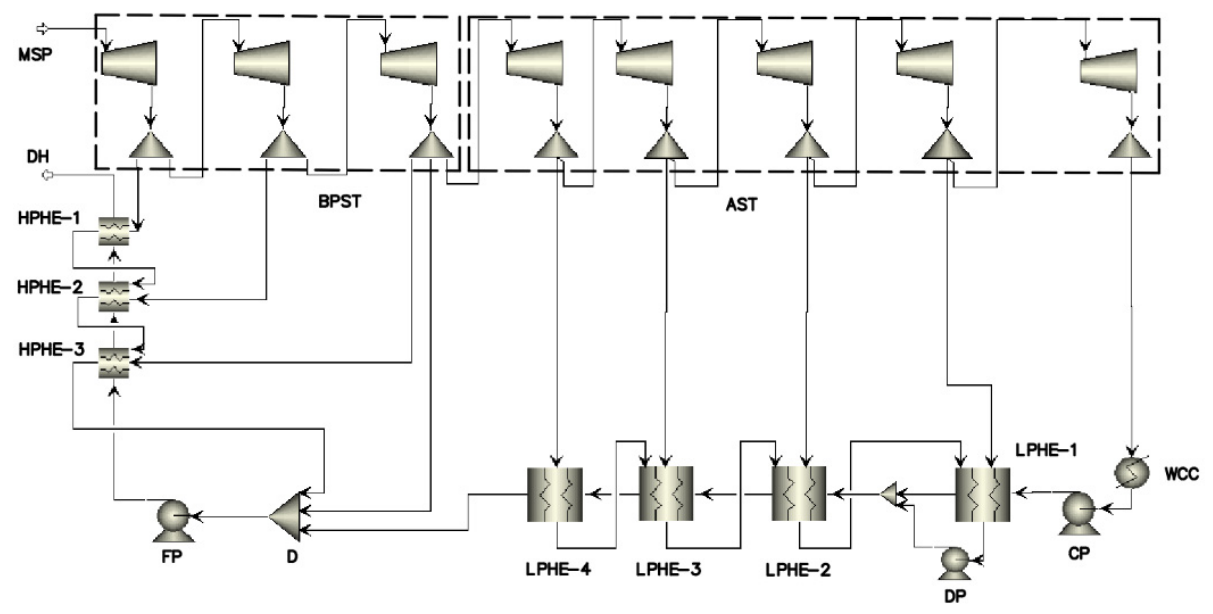

(a)

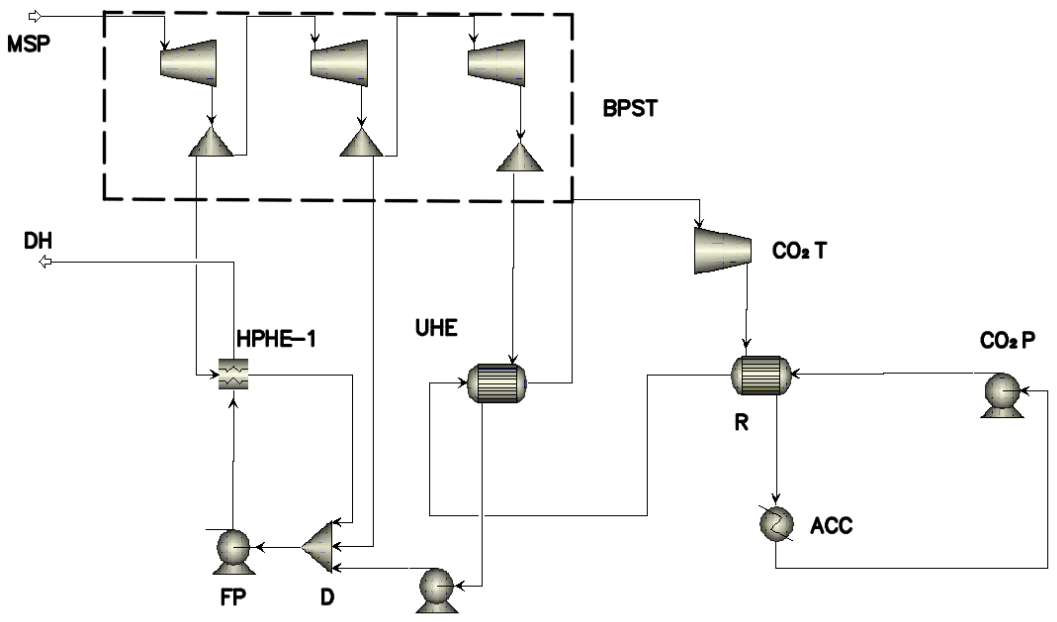

(b)

Figure 3. Simulation flow charts: (a) Case 2a, (b) Case 2b.

The gross power for Case $2 \mathrm{~b}$ was defined as follows:

$$
N_{b r u t_{-} 2 b}^{e}=\left(\left(N_{1_{1}}+N_{1_{2}}+N_{1_{3}}\right)+N_{2 b}\right) \cdot \eta_{m e c h} \cdot \eta_{e g},
$$

$\mathrm{N}_{2 b}$ is the internal power of the $\mathrm{CO}_{2}$ turbine, MW.

The specific amount of $\mathrm{CO}_{2}$ emitted from the TPPs with BPSTs was defined as follows:

$$
S E_{\mathrm{CO}_{2}}=E_{\mathrm{CO}_{2}} / N_{\text {net }}^{e}
$$


where $E_{\mathrm{CO}_{2}}$ is the carbon dioxide emissions mass flow, $\mathrm{kg} / \mathrm{s}$. The carbon dioxide emissions mass flow was defined as a simulation result of the combustion process for the different types of fuels (natural gas and coal).

\section{Results and Discussion}

Thermodynamic Analysis of TPPs with BPSTs

Based on the basic version (Case 1) of heat flow analysis, the following facility parameters were obtained:

1. Gross power of 55.6 MW;

2. Domestic electric power consumption (own needs) of $2 \mathrm{MW}$;

3. Net power of 53.6 MW.

The obtained data on facility performance corresponds well with the research results presented in [28]. The relative error in the net power is $0.8 \%$. The BPST outlet pressure of $1.5 \mathrm{MPa}$ is quite high; therefore, these parameters are practically irrespective of the ambient temperature.

Case 2a modernization heat flow analysis determined the acceptable back pressure at the additional turbine exhaust of 0.65 MPA. This pressure is related to the exhaust limiting humidity of $9 \%[29,30]$. Lower pressure at the additional turbine exhaust was achievable in the case of the intermediate steam superheating application, but this technical solution was reasonable only together with the block facility layout. Most of the installed BPSTs had transversal connections; therefore, this modification version was not considered. In this regard, for the first modernization version, as with the base version, the ambient temperature influence could be neglected.

In Case $2 \mathrm{~b}$ of the low-boiling point heat carrier cycle addition, the ambient temperature influence was remarkable. The analysis results shown in Figure 4 allow for the following conclusions.

At the ambient temperature above $20^{\circ} \mathrm{C}$, it was impossible to use the $\mathrm{CO}_{2}$ cycle with condensation because at the high air temperature, the working fluid temperature at the carbon dioxide pump inlet may reach the critical level of $31^{\circ} \mathrm{C}$, which is prohibitive. In this case, it was possible to make the transition to the supercritical carbon dioxide parameters. This required a replacement in the flow chart of the carbon dioxide pump with the carbon dioxide compressor. At the air temperature of $20^{\circ} \mathrm{C}$, this transition caused the following remarkable performance changes:

1. An increase in the gross power of $7.6 \mathrm{MW}(6.7 \%$ increment) due to the $13.3 \%$ higher carbon dioxide turbine mass flow;

2. A domestic power consumption increase of $7.6 \mathrm{MW}$ ( $29.3 \%$ increment) due to the $13.3 \%$ higher carbon dioxide mass flow rate and the $17.0 \%$ higher compression heat drop (this remarkable change of compression heat drop was related to the transition to gaseous fluid compression);

3. A constant net power output $\left(0 \%\right.$ increment was caused by the equality of the $\mathrm{CO}_{2}$ turbine and compressor power increments).

It is worth mentioning that a $5{ }^{\circ} \mathrm{C}$ air temperature increase in the range of -30 to

$15^{\circ} \mathrm{C}$ caused the following:

1. Mean reduction in the gross power of $0.47 \mathrm{MW}(0.41 \%$ decrement) due to mean reduction in $\mathrm{CO}_{2}$ turbine heat drop of $4.57 \%$ and mean increase in mass flow rate of $6.98 \%$;

2. Mean increase in the domestic power consumption of $0.79 \mathrm{MW}(6.78 \%$ increment) due to mean increase in mass flow rate of $6.98 \%$ and mean increase in $\mathrm{CO}_{2}$ pump heat drop of $0.71 \%$;

3. Mean reduction in the net power of $1.26 \mathrm{MW}$ (1.21\% decrement).

On the other hand, a $5{ }^{\circ} \mathrm{C}$ air temperature increase in the range above $20^{\circ} \mathrm{C}$ caused the following: 
1. Mean increase in the gross power by $3.7 \mathrm{MW}$ ( $3.1 \%$ increment) due to mean reduction in $\mathrm{CO}_{2}$ turbine heat drop of $2.4 \%$ and mean increase in mass flow rate of $8.7 \%$;

2. Mean increase in the domestic power consumption of $6.94 \mathrm{MW}(20.8 \%$ increment $)$ due to mean increase in mass flow rate of $8.7 \%$ and mean increase in $\mathrm{CO}_{2}$ compressor heat drop of $10.65 \%$;

3. Reduction in the net power of 3.24 MW (3.7\% decrement).

Distribution of the heat supplied to TPPs with BPSTs, as shown in Figure 5, showed remarkable potential for increasing the power output:

- $\quad$ By 74\% (Case 2a: increase from 20.69 to 36.08\%);

- $\quad$ By $65 \%$ (Case $2 \mathrm{~b}$ (with $\mathrm{CO}_{2}$ condensation): increase from 20.69 to $34.03 \%$ );

- By $56 \%$ (Case $2 \mathrm{~b}$ (without $\mathrm{CO}_{2}$ condensation): increase from 20.69 to $34.03 \%$ ).

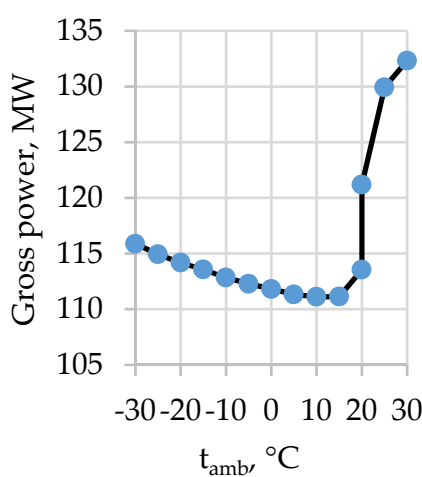

(a)

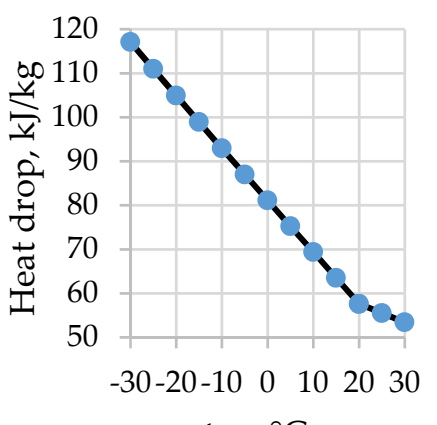

$\mathrm{t}_{\mathrm{amb}},{ }^{\circ} \mathrm{C}$

(d)

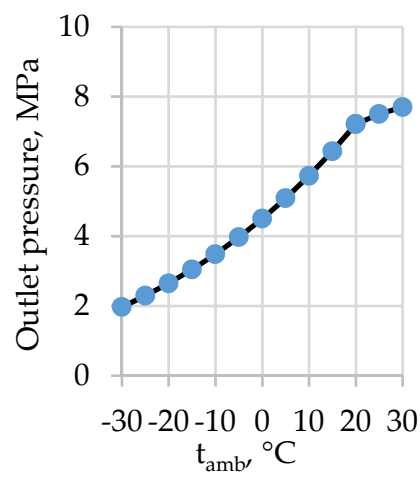

(g)

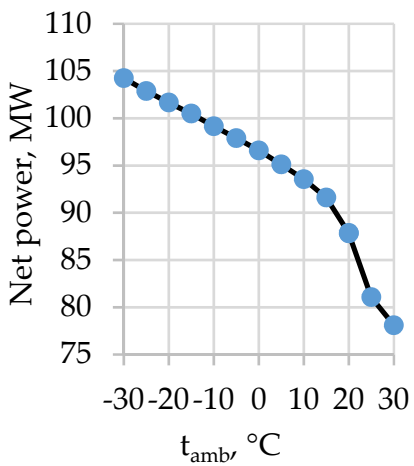

(b)

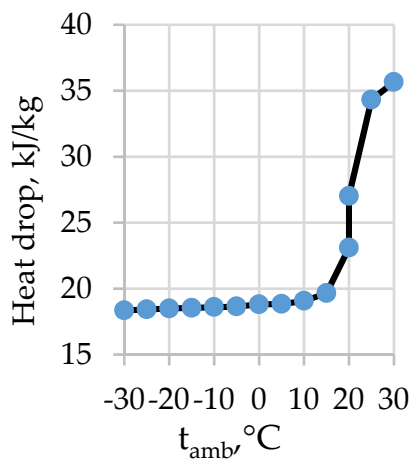

(e)

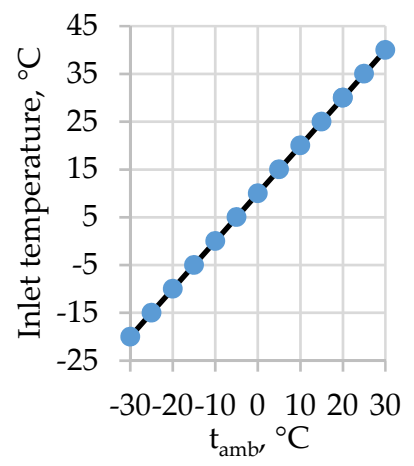

(h)

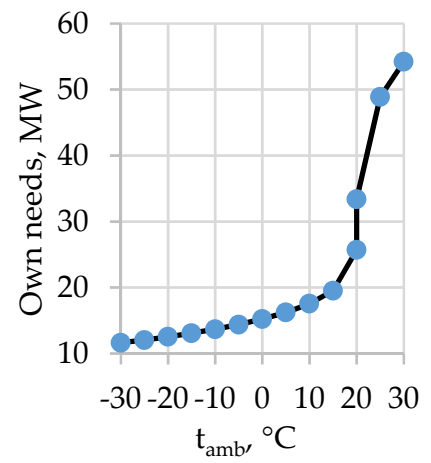

(c)

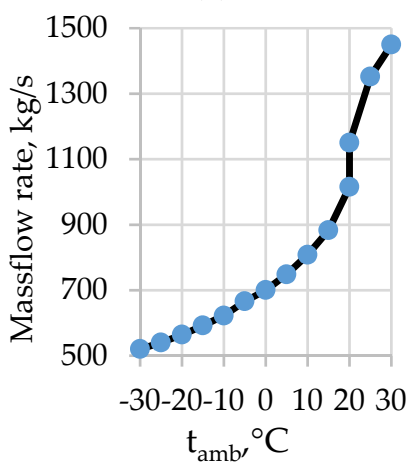

(f)

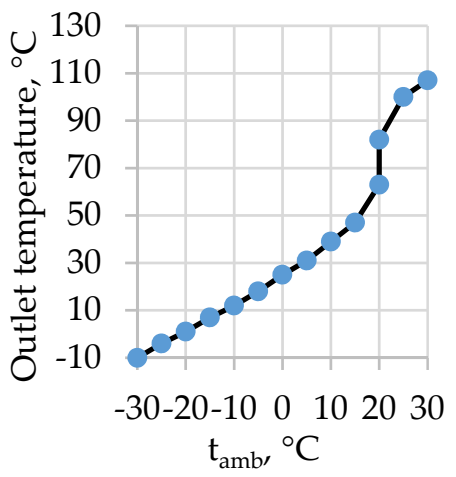

(i)

Figure 4. Ambient temperature influence on the performance of modified TPPs with BPSTs (Case 2b): (a) gross power, (b) net power, (c) own needs, (d) $\mathrm{CO}_{2}$ turbine heat drop, (e) $\mathrm{CO}_{2}$ pump/compressor heat drop, (f) mass flow rate, (g) $\mathrm{CO}_{2}$ turbine outlet pressure, (h) $\mathrm{CO}_{2}$ pump/compressor inlet temperature, and (i) $\mathrm{CO}_{2}$ pump/compressor outlet temperature. 


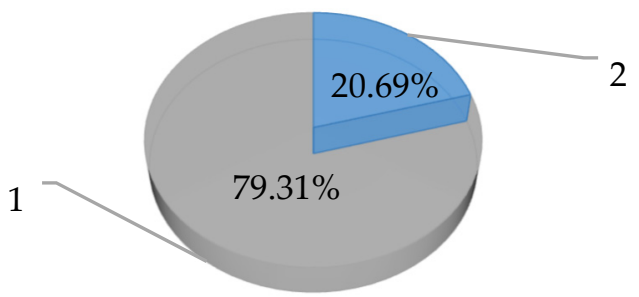

(a)

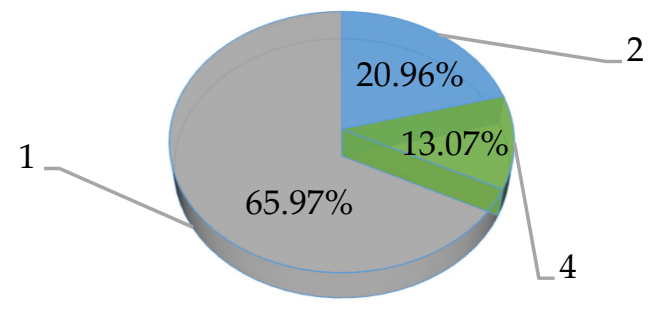

(c)

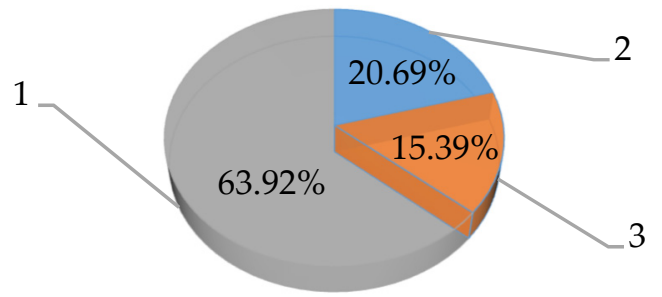

(b)

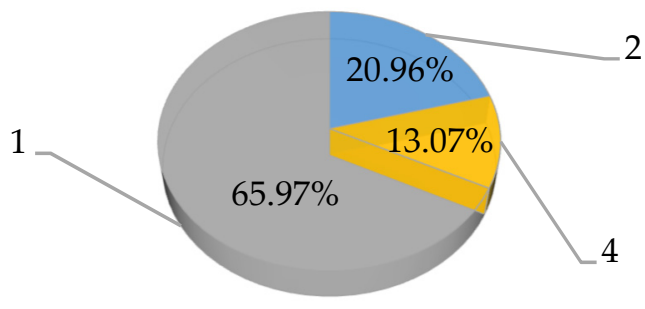

(d)

Figure 5. The heat of fuel combustion structure for the different TPPs with BPSTs producing electricity (without heat load) at the ambient temperature of $20^{\circ} \mathrm{C}$. 1-the net power of BPST power unit; 2-the heat losses in the cold source; 3-the net power of LPT power unit; 4 - the net power of $\mathrm{CO} 2$ power unit. (a) Case 1, (b) Case 2a, (c) Case $2 b$ (with $\mathrm{CO}_{2}$ condensation), and (d) Case $2 \mathrm{~b}$ (without $\mathrm{CO}_{2}$ condensation).

According to the results presented in Figure 6, the superstructure of the AST did not remarkably increase domestic consumption. On the contrary, the superstructure of the carbon dioxide cycle with the low-boiling point heat carrier increased the domestic consumption by $25.7 \mathrm{MW}$, which is attributed to the higher power supplied to carbon dioxide compression devices.

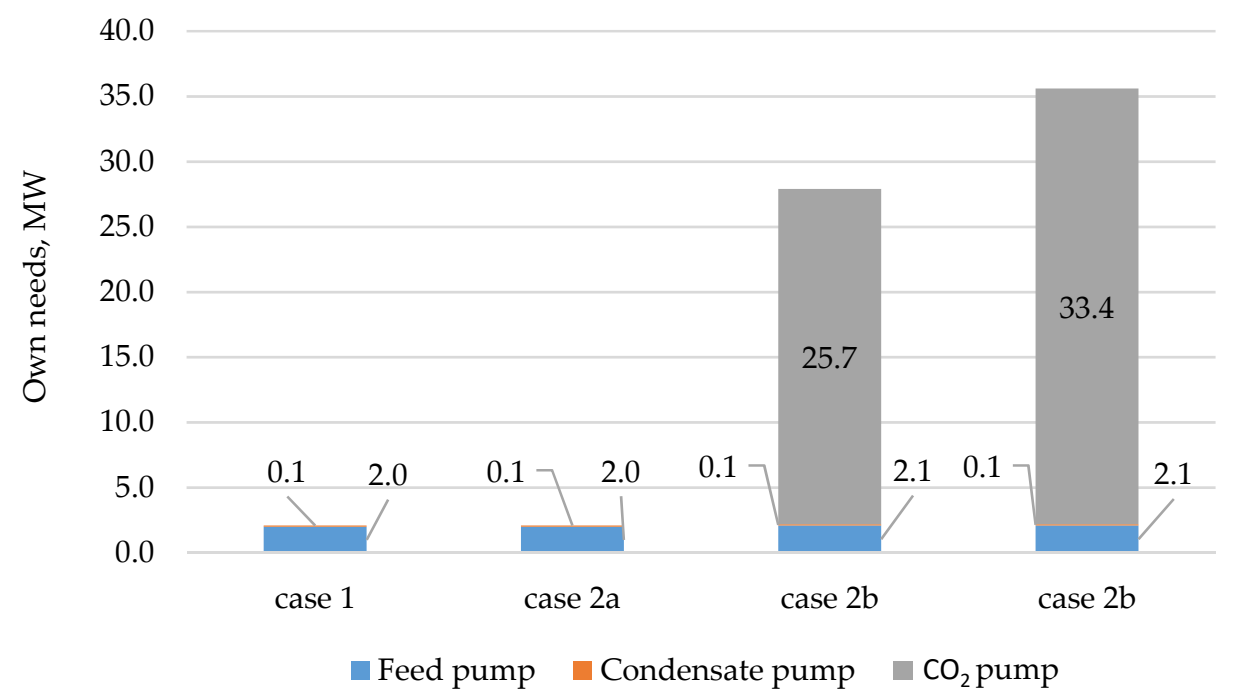

Figure 6. Own needs structure for the different TPPs with BPSTs producing electricity (without heat load) at the ambient temperature of $20^{\circ} \mathrm{C}$.

Table 8 summarizes the assessments of two versions of the modernization effect in prospective BPSTs. 
Table 8. The comparison of the energy effect for modifications of TPPs with BPSTs.

\begin{tabular}{|c|c|c|c|c|c|}
\hline № & TPP Name & $\begin{array}{l}\text { Average Annual } \\
\text { Temperature, }{ }^{\circ} \mathrm{C}\end{array}$ & $\begin{array}{c}\text { Net Power } \\
\text { Increment for } \\
\text { Case } 2 a, M W\end{array}$ & $\begin{array}{c}\text { Net Power } \\
\text { Increment for } \\
\text { Case } 2 b, M W\end{array}$ & $\begin{array}{c}\text { The Choice of } \\
\text { Superstructure } \\
\text { Case }\end{array}$ \\
\hline 1 & Balakovskaya CHP & 7.1 & 94.26 & 94.11 & $2 a$ \\
\hline 2 & Novocheboksarskaya CHP-3 & 3.5 & 69.26 & 70.55 & $2 b$ \\
\hline 3 & Kazanskaya CHP-2 & 4.0 & 69.26 & 70.40 & $2 b$ \\
\hline 4 & Nizhegorodskaya TPP & 5.9 & 76.26 & 76.80 & $2 b$ \\
\hline 5 & Saratovskaya CHP-2 & 7.1 & 94.26 & 94.11 & $2 \mathrm{a}$ \\
\hline 6 & Sterlitamakskaya CHP & 4.9 & 94.26 & 95.30 & $2 b$ \\
\hline 7 & Irkutskaya CHP-9 & 2.2 & 94.26 & 95.59 & $2 b$ \\
\hline 8 & Kemerovskaya ТPP & 1.5 & 79.26 & 81.15 & $2 b$ \\
\hline 9 & Novo-Kemerovskaya CHP & 1.5 & 94.26 & 96.15 & $2 b$ \\
\hline
\end{tabular}

Thus, the thermodynamic studies showed that BPST modernization using the superstructure of a carbon dioxide cycle is thermodynamically reasonable at an ambient temperature below $7{ }^{\circ} \mathrm{C}$ (Figure 7).

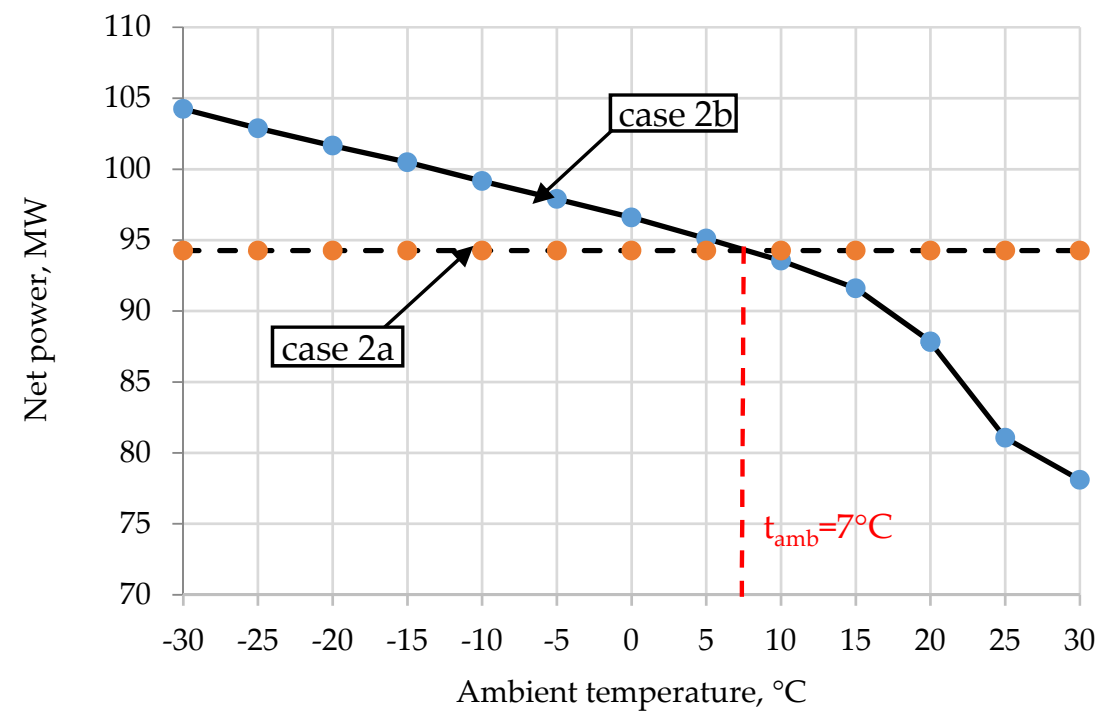

Figure 7. Diagram for the choice of TPPs with BPSTs modification type.

The prospective power plant location scheme with the recommended modernization type is shown in Figure 8. The dark blue color shows the TPPs for Case 2a modernization; the red color shows Case $2 b$ TPPs.

Thus, the modernization method for a BPST by the superstructure of a carbon dioxide power cycle proposed in this work is advisable to use for seven of nine underloaded TPPs. The total increase in the net power for this case is $585.9 \mathrm{MW}$. In turn, the LPT superstructure is expedient for two of nine TPPs: the total increase in the net power, in this case, is 188.5 MW.

It is important to note that the implementation of the described modernization methods will provide not only a significant increase in TPP energy efficiency but also contribute to the average reduction in specific $\mathrm{CO}_{2}$ emissions. This effect is since the additional power is produced at the expense of the utilization of useless low-potential heat without an increase in fuel consumption.

An alternative way to upgrade the energy sector is the creation of oxy-fuel combustion power cycles [31-33]. The net efficiency of such power units can exceed $50 \%$ with an almost complete absence of emissions of harmful substances into the atmosphere. However, unlike the closed supercritical $\mathrm{CO}_{2}$ Brayton cycles, the semi-closed cycles with oxy-fuel combustion are still at the stage of experimental research. Therefore, the TPPs' modification 
cases described in this work should be considered as one of the priority directions for increasing energy efficiency and environmental safety of electricity production in Russia.

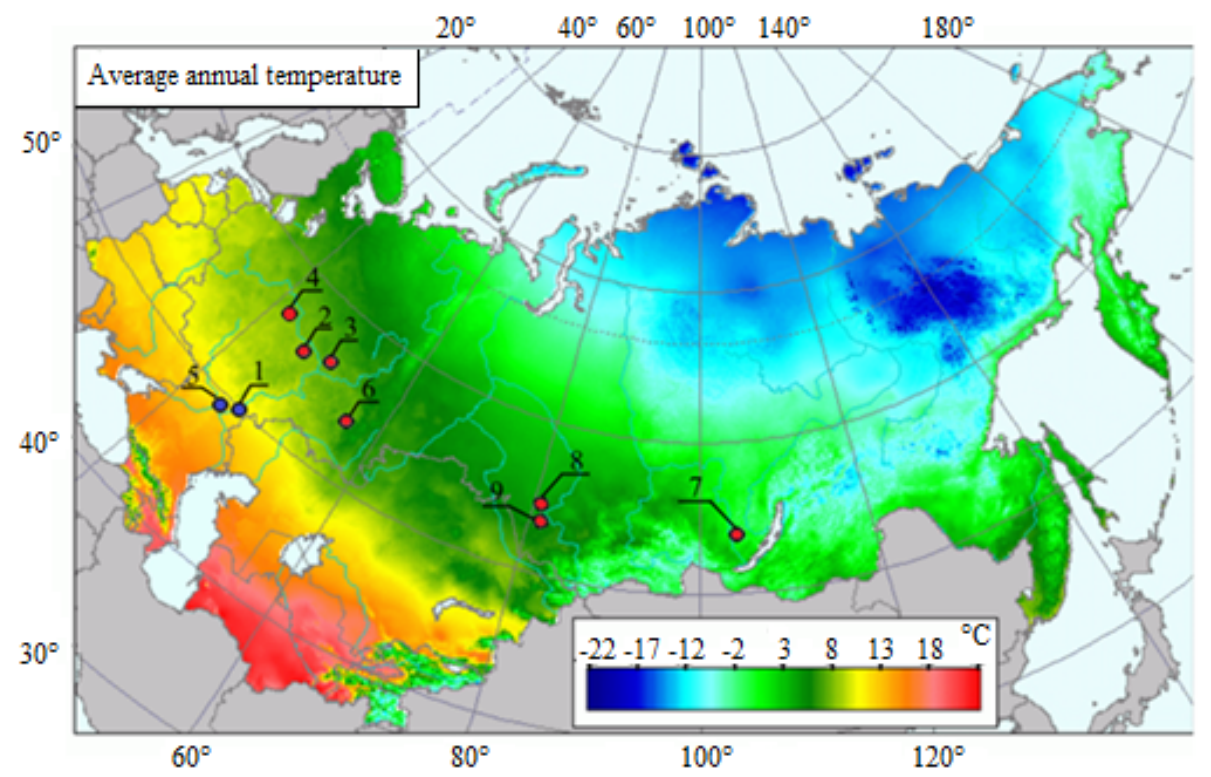

Figure 8. The location scheme for the modified TPPs with BPSTs in Russia. Blue point-for case 2a; red point-for case $2 b$.

\section{Conclusions}

(1) The review of the performance of TPPs with BPSTs in Russia allowed us to identify nine decommissioned facilities and facilities operating at low loads that are prospective objects for modernization directed towards the increase in power production and transition to the electric load. The results of the thermodynamic studies showed that the prospective modification methods for the existing BPST are as follows:

- $\quad$ The superstructure of the accessory steam turbine (Case 2a, Figure 2a);

- $\quad$ The superstructure of the low-boiling point $\mathrm{CO}_{2}$ cycle (Case 2b, Figure 2b).

(2) The recommendations for superstructure type choice were formed based on modeling results. In particular, it was found that the thermodynamically reasonable version of the BPST modification is the addition of a power production facility on carbon dioxide (Case $2 b$ ) for an ambient temperature above $7^{\circ} \mathrm{C}$. At the ambient temperature of $-30{ }^{\circ} \mathrm{C}$, the Case $2 \mathrm{~b}$ version resulted in a $10.8 \%$ increase in the net power. On the other hand, the Case $2 a$ version resulted in a $20.3 \%$ increase in the net power at the ambient air temperature of $+30{ }^{\circ} \mathrm{C}$. In sum, the average annual temperature is a key factor for the choice of BPST modification version.

(3) It was found that it is impossible to implement a cycle with low-boiling point heat carrier condensation at the ambient air temperature above $20^{\circ} \mathrm{C}$. In this case, it was possible to make a transition to the supercritical carbon dioxide parameters. However, this solution required a heat flow scheme change from the carbon dioxide pump to the carbon dioxide compressor.

(4) The implementation of both variants of modifications of TPPs with BPSTs involved the purchase of additional equipment and the exclusion of part of the existing equipment. In Case 2a, it was necessary to include a low-pressure turbine, a generator 2, low-pressure heat exchangers, a water-cooled condenser, and a drainline pump into the scheme, and to replace the low-pressure condensate pump with a high-pressure condensate pump. On the contrary, in the Case $2 \mathrm{~b}$ modification, it was necessary to include a $\mathrm{CO}_{2}$ turbine, a generator 2, an air-cooled condenser, a $\mathrm{CO}_{2}$ pump, and a utilization heat exchanger into the scheme, and to replace the low-pressure condensate pump and low-pressure deaerator with a high-pressure condensate pump and a high-pressure deaerator, respectively. 
(5) The analysis showed the achievable power increase using different BPST modernization versions. Based on the analysis, the modified version is recommended depending upon the ambient air mean annual temperature. The modernization method for BPST by the superstructure of a carbon dioxide power cycle will lead to an increase in the net power by 585.9 MW at seven underloaded thermal power plants with BPST. In turn, the LPT superstructure is expedient for two TPPs with BPST and will result in an increase in the net power by $188.5 \mathrm{MW}$.

(6) A promising area for further research is the economic assessment of the proposed superstructure solution for thermal power plants with back-pressure steam turbines.

Author Contributions: Conceptualization, V.K.; methodology, N.R. and V.K.; software, I.K. and D.L.; validation, I.K. and S.O.; formal analysis, O.Z.; investigation, V.K., I.K. and D.L.; resources, O.Z.; data curation, I.K. and S.O.; writing (original draft preparation), V.K.; writing (review and editing), N.R. and O.Z.; visualization, O.Z. and D.L.; supervision, N.R.; project administration, N.R.; funding acquisition, O.Z. All authors have read and agreed to the published version of the manuscript.

Funding: This study was conducted by the Moscow Power Engineering Institute and was financially supported by the Ministry of Science and Higher Education of the Russian Federation (project no. FSWF-2020-0020).

Institutional Review Board Statement: Not applicable.

Informed Consent Statement: Not applicable.

Conflicts of Interest: The authors declare no conflict of interest.

\section{References}

1. Ma, G.; Zhang, Y.; Yue, M.; Shi, Y. Thermal economy study on the waste heat utilization of a double reheat unit under coupled steam turbine and boiler. Appl. Therm. Eng. 2020, 175, 115112. [CrossRef]

2. Thanganadar, D.; Asfand, F.; Patchigolla, K.; Turner, P. Techno-economic analysis of supercritical carbon dioxide cycle integrated with coal-fired power plant. Energy Convers. Manag. 2021, 242, 114294. [CrossRef]

3. Morimoro, W. Validation Results of 1650 C Class JAC Gas Turbine at T-point 2 Demonstration Plant. Mitsubishi Heavy Ind. Tech. Rev. 2021, 58, 1.

4. Okajima, Y.; Torigoe, T.; Mega, M.; Kuwabara, M.; Okaya, N. Development of Advanced TBC for $1650{ }^{\circ} \mathrm{C}$ Class Gas Turbine. In ITSC2021; ASM International: Almere, The Netherlands, 2021; pp. 695-699.

5. Ol'khovskii, G.G. The Most Powerful Power-Generating GTUs (a Review). Therm. Eng. 2021, 68, 490-495. [CrossRef]

6. Salwan, G.K.; Subbarao, R.; Mondal, S. Comparison and selection of suitable materials applicable for gas turbine blades. Mater. Today Proc. 2021, 46, 8864-8870. [CrossRef]

7. Nourin, F.N.; Amano, R.S. Review of Gas Turbine Internal Cooling Improvement Technology. J. Energy Resour. Technol. 2021, 143, 080801. [CrossRef]

8. Lytvynenko, O.; Tarasov, O.; Mykhailova, I.; Avdieieva, O. Possibility of using liquid-metals for gas turbine cooling system. In Design, Simulation, Manufacturing: The Innovation Exchange; Springer: Cham, Switzerland, 2020; pp. 312-321.

9. Bozhko, V.V. Modernization of the type "P" turbines aimed at their transition to the heat supply schedule. Exp. Oper. Modif. Turbines. Available online: http://www.combienergy.ru/stat/908-Modernizaciya-turboustanovok-tipa-Rs-celyu-ih-perevoda (accessed on 12 June 2021).

10. Gribkov, A.M. Version of the CHP turbine axial location with the power generator placed on the HPT side. Therm. Power Ind. 2013, 3, 69.

11. Ryzhenkov, V.A. Efficient protection against atmospheric corrosion of power production equipment during the repair and long-term standby periods. Reliab. Saf. Power Ind. 2017, 1, 43-46.

12. Khlebalin Yu, M. Modernization of TPP with back-pressure turbine and intermediate superheating. Power Prod. Ind. 2005, 8, 2-4.

13. Gafurov, A.M. Recovery of the low potential exhaust heat for the TPP efficiency increase during winter periods. Tatarstan Power Ind. 2014, 3-4, 69-76.

14. Galashov, N.N.; Tsibulsky, S.A. Analysis of the efficiency of a triple combined cycle gas turbine. Bulletin of the Tomsk Polytechnic University. Georesour. Eng. 2014, 4, 33-38.

15. Song, J.; Li, X.; Ren, X.; Gu, C. Performance analysis and parametric optimization of supercritical carbon dioxide $\left(\mathrm{S}-\mathrm{CO}_{2}\right) \mathrm{cycle}$ with bottoming Organic Rankine Cycle (ORC). Energy 2018, 143, 406-416. [CrossRef]

16. Grinman, M.I.; Fomin, V.A. Application prospects of power production facilities on low boiling heat carrier. Compress. Equip. Pneum. 2009, 7, 35-39.

17. Rogalev, A.; Rogalev, N.; Kindra, V.; Komarov, I.; Zlyvko, O. Research and Development of the Oxy-Fuel Combustion Power Cycles with $\mathrm{CO}_{2}$ Recirculation. Energies 2021, 14, 2927. [CrossRef] 
18. Saleh, B.; Koglbauer, G.; Wendland, M.; Fischer, J. Working fluids for low-temperature organic Rankine cycles. Energy 2007, 32, 1210-1221. [CrossRef]

19. Wang, D.; Ling, X.; Peng, H.; Liu, L.; Tao, L. Efficiency and optimal performance evaluation of organic Rankine cycle for low grade waste heat power generation. Energy 2013, 50, 343-352. [CrossRef]

20. Bao, J.J.; Zhao, L.; Zhang, W.Z. A novel auto-cascade low-temperature solar Rankine cycle system for power generation. Sol. Energy 2011, 85, 2710-2719. [CrossRef]

21. Rogalev, A.; Rogalev, N.; Kindra, V.; Zlyvko, O.; Vegera, A. Study of Low-Potential Heat Utilization Methods for Oxy-Fuel Combustion Power Cycles. Energies 2021, 14, 3364. [CrossRef]

22. Rogalev, N.; Rogalev, A.; Kindra, V.; Komarov, I.; Zlyvko, O. Structural and Parametric Optimization of S-CO $\mathrm{C}_{2} \mathrm{Nuclear} P o w e r$ Plants. Entropy 2021, 23, 1079. [CrossRef] [PubMed]

23. Rogalev, A.; Kindra, V.; Komarov, I.; Osipov, S.; Zlyvko, O. Structural and Parametric Optimization of S-CO 2 Thermal Power Plants with a Pulverized Coal-Fired Boiler Operating in Russia. Energies 2021, 14, 7136. [CrossRef]

24. Yu, X.; Xiao, Z.; Xie, D.; Wang, C.; Wang, C. A 3D method to evaluate moisture losses in a low pressure steam turbine: Application to a last stage. Int. J. Heat Mass Transf. 2015, 84, 642-652. [CrossRef]

25. Voronin, V.P. Some areas of technical re-equipment of CHP plants. Therm. Eng. 2002, 12, 2-11.

26. Dubrovsky, V.G.; Zubov, A.P.; Koshelev, S.A. Reconstruction of a CHP plant in conditions of reduction or release of steam for production needs. Therm. Eng. 2018, 6, 21-28.

27. Bidkar, R.A.; Mann, A.; Singh, R.; Sevincer, E.; Cich, S.; Day, M.; Moore, J. Conceptual designs of 50 MWe and 450 MWe supercritical $\mathrm{CO}_{2}$ turbomachinery trains for power generation from coal. Part 1: Cycle and turbine. In Proceedings of the 5th International Symposium-Supercritical $\mathrm{CO}_{2}$ Power Cycles, San Antonio, TX, USA, 28-31 March 2016; Volume 2, pp. $28-31$.

28. Melnikov, A.S.; Popov, B.I. Determination of the efficiency of condensing and heating turbine units based on the energy characteristics of turbines. Proc. Natl. Acad. Sci. Belarus A Ser. Phys. Tech. Sci. 2020, 64, 438-446. Available online: http: / / vestift.belnauka.by/jour/issue/view/33 (accessed on 24 June 2021).

29. Kawagishi, H.; Onoda, A.; Shibukawa, N.; Niizeki, Y. Development of moisture loss models in steam turbines. Heat Transf.-Asian Res. 2013, 42, 651-664. [CrossRef]

30. Sengupta, B.; Bhattacharya, C. Investigation of energy loss on fractional deposition in last stages of condensing steam turbine due to blade shape and moisture droplet size. J. Eng. Gas Turbines Power 2018, 140, 072601. [CrossRef]

31. Imteyaz, B.; Tahir, F.; Habib, M.A. Thermodynamic assessment of membrane-assisted premixed and non-premixed oxy-fuel combustion power cycles. J. Energy Resour. Technol. 2021, 143, 052303. [CrossRef]

32. Wei, X.; Manovic, V.; Hanak, D.P. Techno-economic assessment of coal-or biomass-fired oxy-combustion power plants with supercritical carbon dioxide cycle. Energy Convers. Manag. 2020, 221, 113143. [CrossRef]

33. Wimmer, K.; Sanz, W. Optimization and comparison of the two promising oxy-combustion cycles NET Power cycle and Graz Cycle. Int. J. Greenh. Gas Control 2020, 99, 103055. [CrossRef] 